Open Access

\title{
New era and challenges for a consolidated journal in educational technology in higher education
}

Josep M. Duart ${ }^{*}$ (i) and Rosalind James

* Correspondence: jduart@uoc.edu Universitat Oberta de Catalunya, Barcelona, SPAIN
We are pleased to announce the start of a new era for this journal, which was founded in 2004 by the Open University of Catalonia (UOC). It will provide researchers working in the field of educational technology (e-learning) in higher education with a publication to disseminate the results of their studies. The first issue of this open-access online journal was published under the name of Revista de Universidad y Sociedad del Conocimiento, the abbreviated form of which - RUSC - has been used to refer to the journal for 10 years. The first volumes were published in Spanish but, from 2010 onwards, all articles were published in both Spanish and English. Also in 2010, we decided to change the name of the journal to RUSC. Universities and Knowledge Society Journal. It was an important year because the journal was incorporated into renowned citation databases like Scopus. Then, in 2013, a co-edition agreement between UOC and the University of New England (UNE) was signed in order to drive the journal's internationalisation strategy forward.

Since its launch, the number of articles published, downloaded and cited has increased year on year, and particularly so since the 2013 agreement with UNE. We are now indexed in Scopus, Web of Science (ESCI), Google Scholar, Educational

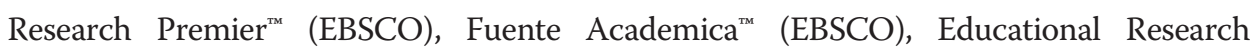
Abstracts (ERA), ACER (Australian Council for Educational Research), IRESIE, ISOC (CSIC/CINDOC), Dialnet, DOAJ, Dulcinea, OAISTER, Scientific Commons, Redalyc, e-Revistas, and SHERPA/RoMEO.

Twelve years and more than 250 published articles later, we are presenting the start of a new and promising chapter for the journal, which will now be known as the International Journal of Educational Technology in Higher Education (ETHE). The new name is the result of some considerable thought given to how best to summarise the journal's thematic scope-that of studying and analysing the use of technology in teaching and learning processes in higher education. The change of name has come about as a result of a new publication agreement; from 2016, the journal will be published by Springer on the SpringerOpen platform. 
For this new stage, we wanted to retain the basic principles that have always governed the journal:

a) The selection of high-quality content in the field of educational technology in higher education through a rigorous peer-review process.

b) The online dissemination of content in open-access format, under open-access licence terms.

c) The international and multicultural vision of the analysis of the journal's study areas.

The SpringerOpen platform allows us to retain and strengthen these principles, and that is why it was chosen for this new stage of the journal.

ETHE aims to provide a vehicle for scholarly presentation and exchange of information between professionals, researchers and practitioners in the technology-enhanced education field; contribute to the advancement of scientific knowledge regarding the use of technology and computers in higher education; and inform readers about the latest developments in the application of information technologies (ITs) in higher education learning, training, research and management. We encourage authors to submit papers related, but not limited, to the following topics of interest:

- Innovation and best practices in online learning, training, research and management

- Educational technology, models and trends in higher education

- Computer-supported collaborative learning, training and research

- Intelligent tutoring and mentoring systems

- Learning analytics and educational data mining

- Open access systems for learning and training

- Organisational and administrative perspectives of IT use in higher education

- University governance and leadership in the knowledge society

- Institutional policies, standards and assessment methods

- Models of higher education presence and service using the Internet

- Internationalisation and cultural aspects of online learning, training and research

Springer offers authors and reviewers access to the best tools for ensuring a smooth, effective peer-review process. The academic and scientific control of the process will be assured by members of the extensive and prestigious, newly-appointed International Editorial Board and a considerable number of expert reviewers, some of whom have been collaborating with the journal for many years, while others have recently joined. The publication's academic quality and thematic areas shall remain under the control of UOC through the editors-in-chief, and editorial management shall be provided by the executive editor.

SpringerOpen allows simple, straightforward access to content, displaying articles suited to the readers needs, with accessible menus and references. Articles are published under the Creative Commons BY 4.0 licence.

The journal's international scope is more evident in this new chapter. We have chosen English as the journal's language. For an international journal like ETHE, English plays the role of a shared language of scholarly communication. By settling 
on a single language, we remain committed to authors and readers from Spanish- and Portuguese-speaking countries - where the journal is very popular - by offering them better opportunities to use ETHE as a vehicle for the international dissemination of their research thanks to the partnership with Springer. We shall also remain sensitive to the analysis of research issues connected with the use of technology in teaching and learning processes in higher education in different world regions. Indeed, this has always been one of the distinctive traits of our journal, and it is our intention that it should continue to be so. It is also our intention to carry on improving the journal's presence and impact in world areas where other languages are spoken, such as Asia, the Far East and Africa. We shall make every effort to ensure that using a single language does not mean a single world view. Rather, our aim is to ensure that ETHE is a broad-based shared vehicle for scholarly communication.

In order to meet the objectives we have set ourselves in terms of the journal's content quality and international scope, we have configured an extensive International Editorial Board formed by prestigious researchers working in the journal's thematic areas. We hope to capture the most influential areas of research at all times and to encourage the analysis of the most significant research issues from local, regional and international perspectives.

At this new stage, any author wishing to publish in ETHE will have more services and facilities at their disposal than they did previously. With Springer, we are able to provide new tools, new mechanisms to control the quality of academic and editorial processes, and many more opportunities and means of disseminating the knowledge we publish. Additionally, Springer will facilitate wider promotion of the journal and, hence, our authors' work. We would like to take advantage of this editorial space to thank all of the editing teams at UOC as well as their collaborators (editors, translators and other professionals) whose support over the years has made it possible to publish the journal to exacting standards of quality. This has also been made possible by the executive editor, who has coordinated the entire editorial organisation and will continue to do so in the new stage of the journal.

It is important for us to record our recognition of and express our thanks to all of the authors who, over the past 12 years, have placed their trust in the journal for the dissemination of their research. It is thanks to them that the journal has reached the levels of recognition and positioning that it has today. Readers have unquestionably played a crucial part in this growth, and we would like to thank you all for your support. We are starting this new era with great excitement and with the confidence of knowing that we have a prestigious International Editorial Board, an excellent team of reviewers and a significant number of authors and readers all over the world. And we are doing so with the determination and will to carry on striving for excellence and academic rigour, and disseminating the results of high-quality research on educational technology in higher education from across the globe.

Josep M. Duart and Rosalind James

Received: 10 December 2015 Accepted: 23 December 2015

Published online: 09 February 2016 